Journal of Information System, Applied, Management, Accounting and Research. http://journal.stmikjayakarta.ac.id/index.php/jisamar , jisamar@stmikjayakarta.ac.id, jisamar2017@gmail.com

e-ISSN: 2598-8719 (Online), p-ISSN: 2598-800 ( Printed), Vol. 5 No. 1 , Februari 2021

\title{
KINERJA KEUANGAN PT BALAI PUSTAKA (PERSERO) SESUDAH DAN SEBELUM MERGER BERDASARKAN SURAT KEPUTUSAN MENTERI BUMN NOMOR: KEP-100/MBU/2002
}

\author{
Gemala Paramita $^{1}$, Yudo Kisworo ${ }^{2}$, Nurul Musqari ${ }^{3}$ \\ Program Studi Manajemen ${ }^{1}$, Program Studi Manajemen ${ }^{2}$, Program Studi \\ Manajemen $^{3}$ \\ Fakultas Ekonomi ${ }^{1}$, Fakultas Ekonomi ${ }^{2}$, Fakultas Ekonomi ${ }^{3}$ \\ Universitas Ibnu Chaldun ${ }^{1}$, Universitas Ibnu Chaldun ${ }^{2}$, Universitas Ibnu \\ Chaldun $^{3}$ \\ Email: gemala_paramita@yahoo.com ${ }^{1}$, Email: yudo.kisworo@yahoo.co.id \\ ${ }^{2}$, Email: nurul_musqari@yahoo.com ${ }^{3}$
}

\begin{abstract}
Abstrak: Penelitian ini bertujuan untuk mengetahui kinerja keuangan PT Balai Pustaka (Persero) 2011 - 2017. Penelitian ini menggunakkan perhitungan Rasio Keuangan berdasar Surat Keputusan Menteri Badan Usaha Milik Negara Nomor: KEP- 100/MBU/2002 pada PT Balai Pustaka (Persero). Hasil penilaian kinerja keuangan PT Balai Pustaka (Persero) 2011, 2013, dan 2017 menunjukkan bahwa perusahaan mendapatkan predikat Kurang Sehat Kategori B dan pada tahun 2012, 2014, 2015, dan 2016 mengalami penurunan dengan tingkat kesehatan sehat kategori C (Tidak Sehat).
\end{abstract}

Kata Kunci: Kinerja Keuangan, PT Balai Pustaka (Persero), Merger

Abstract: This study aims to determine the financial performance of PT Balai Pustaka (Persero) 2011 - 2017. This study uses the calculation of financial ratios based on the Decree of the Minister of State-Owned Enterprises Number: KEP- 100 / MBU / 2002 at PT Balai Pustaka (Persero). The results of the financial performance assessment of PT Balai Pustaka (Persero) 2011, 2013, and 2017 show that the company received the title of Unhealthy Category B and in 2012, 2014, 2015, and 2016 decreased with a healthy level of health in category C (Unhealthy).

Keywords: Financial Performance, PT Balai Pustaka (Persero), Merger

Ciptaan disebarluaskan di bawah Lisensi Creative Commons Atribusi 4.0 Internasional. 


\section{PENDAHULUAN}

Di Amerika Serikat, aktivitas merger merupakan hal biasa terjadi. Bahkan di era 1980-an telah terjadi kira-kira 55.000 aktivitas sehingga tahun 1980-an sering disebut sebagai dekade merger mania (Hitt, 2002). Sementara itu, aktivitas merger di Indonesia mulai marak dilakukan seiring dengan majunya pasar modal di Indonesia. Ada beberapa alasan mengapa perusahaan lebih memilih melakukan merger are untuk dijadikan strategi pertumbuhan internal, pendekatan jalan pintas guna tujuan perusahaan dapat dicapai tanpa perlu memulai bisnis dari awal. Nilai total perusahaaan setelah merger yang lebih besar jika nilai masing-masing perusahaan dijumlahkan sebelum merger dan akuisisi. Merger dan akuisisi juga bisa memberikan keuntungan yang tinggi perusahaan yaitu dengan peningkatan kemampuan pemasaran, riset, keterampilan manajerial, transfer teknologi, dan penyediaan biaya produksi (Vally Auqie, 2013).

Untuk menilai bagaimana merger yang dilakukan, kita dapat melihatnya dari kinerja perusahaan yang melakukan merger. Menurut Payamta dan Setiawan (2004), kinerja merupakan hasil nyata yang dicapai dan dipergunakan untuk menunjang kegiatan dalam suatu perusahaan. Pengukuran kinerja suatu perusahaan dapat dilihat dari rasio keuangan atau pun return saham. Informasi rasio keuangan bersumber dari laporan keuangan perusahaan yang berhubungan (Novaliza dan Djajanti, 2013).

Selain itu, menurut Subramanyam dan Wild (2010: 42), analisis rasio dapat mengungkapkan hubungan penting dan menjadi dasar perbandingan dalam menernukan kondisi dan tren yang sulit untuk dideteksi dengan mempelajari masing-masing komponen yang membentuk rasio.

Balai Pustaka didirikan dengan nama Commissie voor de Inlansche School en Volkslectuur (bahasa Belanda: "Komisi untuk Bacaan Rakyat") oleh pemerintah Hindia Belanda pada tanggal 15 Agustus 1908. Lembaga itu berada di bawah naungan Adviseur voor Inlandsch Zaken, atau Biro Penasehat Urusan Pribumi, yang termasuk ke dalam Departement van Onderwijs en Eeredienst, Departemen Pendidikan dan Keagamaan. Kantoor voor de Volkslectuur atau lebih dikenal dengan nama "Balai Poestaka" pada tanggal 17 September 1917. Balai Pustaka menerbitkan kira-kira 350 judul buku per tahun yang termasuk kamus, buku referensi, keterampilan, sastra, sosial, politik, agama, ekonomi, dan penyuluhan.

Menurut Menteri BUMN, Mustafa Abubakar, Balai Pustaka pada era tahun 2011, terancam bangkrut dan akan dilikuidasi karena terus mengalami kerugian. BP terus merugi dan meninggalkan banyak utang. Gayung bersambut, rencana mengakuisisi BP semakin nyata setelah Menteri Badan Usaha Milik Negara (BUMN) kala itu, Dahlan Iskan, yang mewacanakan wacana tersebut. Dahlan memberi waktu tiga bulan bagi PT Telkom untuk mengakuisisi Balai Pustaka. BP di ujung tanduk. Kabar wacana akuisisi sontak membuat gerah para karyawan.

Wacana itu ditentang keras. Terjadi perlawanan dari dalam, terutama pengurus BP yang sudah mengabdi selama puluhan tahun di perusahaan publikasi itu. Mereka yakin BP bisa bertahan.

Desember 2011, Balai Pustaka melakukan merger dengan PT Pradnya Paramita, salah satu perusahaan penerbit buku yang gulung tikar. Setelah itu, kantor Balai Pustaka mulai pindah dari kantor di Jalan Gunung Sahari Raya ke kawasan Matraman, Jakarta Timur. Barang milik Paramita juga ikut dijual dan disewa. Upaya itu untuk membantu keuangan perusahaan. Penyebab jatuhnya bisnis Balai Pustaka mulai terlihat sejak berlakunya UU Antipraktik Monopoli pada 2000. Boleh dikata, sebelum UU Antipraktik Monopoli itu diberlakukan, BP merupakan penerbit tunggal proyek buku kurikulum nasional. Sudah pasti, tanpa usaha keras, BP akan menerima keuntungan dari proyek pemerintah setiap tahun. Awal 2004 pasca penerapan UU Antipraktik Monopoli, kondisi pasar perbukuan berubah. Pasar perbukuan semakin kompetitif dengan masuknya perusahaan penerbit. Mau tak mau, BP harus bersaing dengan banyak perusahaan penerbit yang bermunculan. BP tidak siap menyikapi perubahan bisnis. Sejak itu pula, BP mulai menderita kerugian karena kalah bersaing. Setelah 15 tahun menderita kerugian, akhimnya Balai Pustaka berhasil mencatat keuntungan pada tahun 2017. Berdasarkan laporan keuangan BP 2017, keuntungan bisnis BP sebesar Rp 3,2 Miliar. Selain itu, revaluasi aset sebesar Rp 127 Miliar. Sehingga, laba komprehensif yang diraih Balai Pustaka sebesar Rp 131 Miliar.

Penelitian tentang Kinerja Keuangan PT Balai Pustaka (Persero) Sesudah dan Sebelum Merger menjadi menarik untuk dilakukan guna memperoleh informasi tingkat signifikansi perubahan kinerja sebelum sesudah merger.

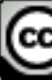




\section{KAJIAN TEORI}

Pengertian merger dalam bukunya Moin, (2003) memaparkan pengertian merger yaitu, merger merupakan salah satu strategi yang diambil perusahaan untuk mengembangkan dan menumbuhkan perusahaan, merger berasal dari kata "mergere" (Latin) yang artinya (1) bergabung bersama, menyatu, berkombinasi (2) mengurangi indikasi karena terserap atau tertelan sesuatu. Merger didefinisikan sebagai penggabungan dua atau perusahaan yang kemudian hanya ada satu perusahaan yang tetap hidup sebagai badan hukum, sementara yang lainnya aktivitasnya atau bubar.

Menurut Moin, (2003) pada prinsipnya terdapat dua motif yang mendorong sebuah melakukun merger yaitu motif ekonomi dan motif non-ekonomi. Motif ekonomi yang berkaitan dengan esensi tujuan perusahaan yaitu meningkatkan nilai perusahaan atau memaksimumkan kemakmuran pemegang saham. Di sisi lain, motif non ekonomi adalah motif yang bukan berdasarkan pada esensi tujuan tersebut, tetapi didasarkan pada keinginan subyektif atau ambisi pribadi pemilik atau manajemen perusahaan.

Salah satu motif strategis dalam keputusan merger yaitu motif ekonomi karena aktivitas merger dan akuisisi dilakukan untuk mencapai posisi strategis perusahaan untuk menghasilkan keunggulan kompetitif. Biasanya perusahaan melakukan merger. dan akuisisi untuk mendapatkan economies of scale dan economies of scope. Dalam perspektif manajemen keuangan, motif ekonomi adalah besar perusahaan menghasilkan keuntungan atau nilai (penciptaan nilai) terutama bagi perusahaan dan bagi pemegang saham. Merger sendiri terkadang memiliki motif ekonomi dengan tujuan jangka panjangnya untuk tercapainya peningkatan nilai. Seluruh aktivitas dan pengambilan keputusan merger haruslah mengarah untuk mencapai tujuan ini (Brigham. 2001).

Alasan utama perusahaan mengambil keputusan merger yaitu untuk menciptakan sinergi. Sinergi itu sendiri adalah nilai total perusahaan setelah merger menjadi lebih besar nilai masigmasing penusahaan sebelum merger jika dijumlahkan sebelum merger dan akuisisi. Selain itu memurut Brigham, (2001) pengaruh sinergi bisa ditimbulkan dari empat sumber yang pertama melakukan Penghematan operasi, yang dilihat dari skala ekonomis dalam manajemen, pemasaran, produksi atau distribusi, yang kedua penghematan keuangan, termasuk biaya transaksi yang rendah, yang ketiga adanya efisiensi, yang berarti bahwa manajemen salah satu perusahaan, lebih efisien ketika aset perusahaan yang lemah akan lebih produktif setelah merger dan, yang terakhir peningkatan penguasaan pasar akibat penurunannya para pesaing.

Diversifikasi adalah strategi pemberagaman bisnis yang dapat dilakukan melalui merger. Diversifikasi dimaksudkan untuk mendukung aktivitas bisnis dan operasi perusahaan untuk layak bersaing. Akan tetapi jika melakukan diversifikasi yang lebih jauh dari semula bisnis, maka perusahaan tidak lagi berada pada koridor yang mendukung kompetensi inti (kompetensi inti). Disamping memberikan manfaat seperti transfer teknologi dan pengalokasian modal, diversifikasi juga mengurangi kerugian yaitu adanya subsidi silang (Brigham, 2001).

Aktivitas merger kadang dilakukan bukan hanya untuk kepentingan ekonomi tetapi juga kepentingan yang bersifat non-ekonomi, seperti untuk meningkatkan prestise, atau hanya ambisi pribadi, dan bisa juga untuk meningkatkan SDM (sumber daya manusia) dari perusahaan yang melakukan merger. Motif non-ekonomi bisa berasal dari manajemen perusahaan atau pemilik (Brigham, 2001).

Dalam bukunya Moin, (2003) menyatakan alasan mengapa perusahaan melakukan merger adalah ada "manfaat lebih" yang diterima, meskipun asumsi ini tidak semuanya terbukti. Secara spesifik, keunggulan dan manfaat merger antara lain adalah:

1. Arus kas dengan cepat karena produk dan pasar sudah jelas.

2. Memperoleh meningkat dana pembiayaan karena kredititor lebih percaya dengan perusahaan yang telah berdiri dan mapan.

3. Medapatkan karyawan yang berpengalamn karna tidak perlu melakukan rekrutmen.

4. Mendapatkan pelanggan yang telah mapan tanpa harus merintis dari awal.

5. Memperoleh sistem oprasional dan administrasi yang sudah berpengalaman.

6. Mengurangi kegagalan bisnis karena sudah memiliki konsumen dan tidak harus mencari konsumen baru.

7. Menghemat waktu untuk memasuki bisnis baru dengan kata lain tidak perlu menyesuaikan dengan lingkungan bisnis baru.

8. Memperoleh infrastruktur yang lebih baik schingga dapat mencapai pertumbuhan yang lebih cepat.

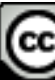

Ciptaan disebarluaskan di bawah Lisensi Creative Commons Atribusi 4.0 Internasional. 
Disamping memiliki keunggulan, merger dan akuisisi juga memiliki kelemahan sebagai berikut:

1. Proses integrasi yang tidak mudah.

2. Kesulitan menentukan nilai perusahaan secara akurat.

3. Biaya konsultan yang mahal.

4. Meningkatnya kompleksitas birokrasi.

5. Biaya koordinasi yang mahal.

6. Sering kali menurunkan moral organisasi.

7. Tidak menjamin peningkatan nilai perusahaan.

8. Tidak menjamin peningkatan kemakmuran pemegang saham.

Beberapa penelitian mengenai pengaruh merger terhadap return saham yang pernah dilakukan oleh Heykal dan Hennisia, (2015) yang meneliti tentang Analisis Hubungan antara Merger dan Akuisisi Terhadap Kinerja Keuangan dan Return Saham pada Perbankan. Selain itu ada Abdourahmane Diaw (2014) yang megemukakan bahwa return saham biasanya menjadi acuan untuk mengukur sebuah nilai dari suatu perusahaan, dalam penelitiannya dia menilai merger dan akuisisi dapat meningkatkan return saham sehingga berdampak positif terhadap pemegang saham, ada juga penelitian yang membandingkan antara perusahaan yang melakukan merger dan perusahaan non merger yang dilakukan oleh Wibowo dan Pakereng (2001), hasilnya menunjukkan bahwa perusahaan yang melakukan merger dan tidak melakukan merger tidak memiliki perbedaan terhadap return saham.

\section{GAMBARAN UMUM PERUSAHAAN}

\section{Profil Perusahaan}

Balai Pustaka bukan sekadar nama perusahaan. Lebih dari itu, ia merupakan jejak panjang peradaban yang tiada henti mencerdaskan dan mencerahkan bangsa. Balai Pustaka memiliki reputasi di bidang penerbitan yang diakui keberadaannya bukan saja di Indonesia, tetapi namanya melegenda sampai ke mancanegara. Sejak berdirinya pada masa penjajahan, Balai Pustaka menjadi pelabuhan perjuangan para tokoh bangsa. Lewat karyakaryanya baik berupa non-ksi maupun ksi, karya para tokoh bangsa tersebut senantiasa menggelorakan semangat kemerdekaan. Karya-karya sastra adiluhung banyak diterbitkan, begitu pun buku-buku ilmu pengetahuan dan keterampilan. Dengan terus menerus melakukan berbagai inovasi, Balai Pustaka mampu melewati dan menjawab tantangan zaman.

Di era milenial yang serba digital, Balai Pustaka kembali melakukan terobosan inovasi dengan bertransformasi ke dalam industri kreatif. Pustaka digital, edutab, audio book, animasi, hingga lm layar lebar menjadi bagian produk pengalihwahanaan berbagai konten yang dimiliki Balai Pustaka.

\section{Sejarah Perusahaan}

Balai Pustaka berdiri pada tanggal 22 September 1917, sebagai kelanjutan dari Commisie voor Inlandsche School en Volklectuur yang dibentuk pada 14 September 1908. Didasari semangat politik etik untuk mencerdaskan rakyat, Balai Pustaka mener bitkan buku-buku dalam berbagai bahasa daerah Nusantara. Balai Pustaka juga menerbitkan majalah dan membentuk ribuan Taman Bacaan Rakyat.

Para pemikir dan pejuang kebangsaan memanfaatkan Balai Pustaka untuk membangun nilai-nilai kebangsaan melalui karya-karya sastra, hingga menggumpal dalam wujud Sumpah Pemuda 1928. Bersama dengan diluncurkannya novel "Salah Asoehan" karya Abdoel Moeis dan dikumandangkannya lagu "Indonesia Raya" untuk yang pertama kali, karya Wage Rudolf Supratman. Setelah kemerdekaan 1945, Balai Pustaka berperan dalam penyediaan buku-buku pendidikan selain terus menjadi penerbit buku sastra dan budaya. Dari waktu ke waktu, status dan fungsi Balai Pustaka terus dikembangkan. Pada 1996, berdasarkan Peraturan Pemerintah Nomor 66, Balai Pustaka ditetapkan menjadi PT (Persero). Di era itu juga menjadi penanda penyebaran sastra Jawa Modern. Jumlah buku berbasa Jawa lebih banyak dibandingkan yang berbahasa Melayu. Langkah maju

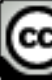


yang dilakukan KBR (Komisi Bacaan Rakyat), yang telah berhasil sebagai pencetak, penerbit, dan penjual majalah, adalah mengubah KBR menjadi Yayasan Resmi Balai Pustaka pada tahun 1917.
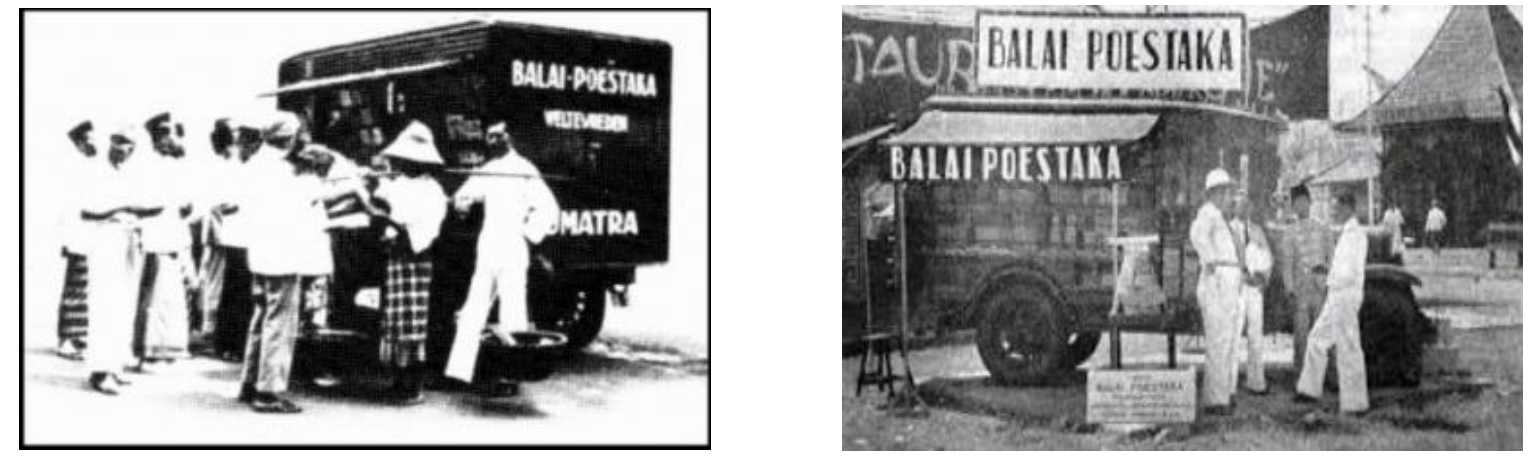

Tujuan lain yang dilakukan oleh KBR yaitu menerjemahkan atau menyadur hasil sastra Eropa hal ini juga bertujuan agar rakyat Indonesia buta terha dap informasi yang berkembang di negara nya sendiri.

\section{Visi dan Misi Perusahaan}

Dalam rangka mewujudkan misi dan mencapai tu juan perusahaan pada kurun waktu 20142018, manajemen menetapkan sasaran umum perusa haan yang dijadikan sebagai parameter pencapaian kegiatan bisnis yang dilakukan pada kurun waktu tersebut, yaitu:

1. Pertumbuhan bisnis yang baik dan berdaya saing dalam hal pengembangan pangsa pasar, kapasitas produksi dan portofolio produk di bidang percetakan, penerbitan, dan multimedia dalam agenda transformasi bisnis perusahaan.

2. Pemulihan dan penguatan manajemen keuangan, tata kelola operasional dan pengawasan yang efektif, efisien, serta berkinerja unggul.

3. Penataan organisasi yang ramping, dinamis, dan produktif serta didukung human capital yang kompeten dan profesional.

\section{Sasaran Perusahaan}

Pencapaian sasaran umum perusahaan dilakukan dengan menetapkan strategi perusahaan. Rumusan strategi yang digunakan perusahaan dalam periode 2014-2018 berdasarkan analisis posisi perusahaan antara lain:

1. Penetrasi pasar melalui pengembangan jaringan pemasaran dengan penunjukan mitra yang terseleksi dan kredibel pada daerah-daerah target pemasaran.

2. Aliansi dan kerja sama produksi dengan rekanan yang kompeten, handal, dan saling menguntung-kan.

3. Investasi secara selektif untuk mesin cetak dan peralatan produksi untuk kebutuhan minimum industri.

4. Pengembangan portofolio percetakan, penerbitan, dan multimedia dengan konsep kehati-hatian dan selektif.

5. Pengembangan organisasi, human capital dan kinerja berbasis kriteria penilaian kinerja unggul.

\section{Strategi}

Pencapaian sasaran umum perusahaan dilakukan dengan menetapkan strategi perusahaan. Rumusan startegi yang digunakan perusahaan dalam periode 2014-2018 berdasarkan Analisa posisi perusahaan antara lain:

a. Penetrasi pasar melalui pengembangan jaringan pemasaran dengan penunjukkan mitra yang terseleksi dan kredibel pada daerah target pemasaran.

b. Aliansi dan Kerjasama produksi dengan produksi dengan rekanan yang kompeten, handal dan saling menguntungkan.

c. Investasi secera selektif untuk mesin cetak dan peralatan produksi untuk kebutuhan minimum industry.

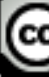

Ciptaan disebarluaskan di bawah Lisensi Creative Commons Atribusi 4.0 Internasional. 
d. Pengembangan protofolio percetakan, penerbitan dan media multimedia dengan konsep kehati-hatian dan selektif.

e. Pengembangan organisasi, human capital dan kinerja berbasis kriteria penilaian yang unggul.

\section{Manajemen}

a. Komisaris Utama PT Balai Pustaka (Persero) : Sukemi

b. Direktur Utama PT Balai Pustaka (Persero) : Saiful Bahri

c. Direktur Komerisal PT Balai Pustaka (Persero) : Akbar Ramli

\section{Kompetensi Bisnis}

Penerbitan • Percetakan • Multimedia • Manajemen Literasi •

○ Penerbitan Buku Budaya \& Karakter :

\begin{tabular}{|l|l|}
\hline Sastra & Bacaan Anak \\
Budaya Nusantara & Pendidikan Anak Usia Dini \\
Sejarah \& Biografi & Penyuluhan/ Perdesaan \\
Spiritualitas & Keterampilan \&Kewirausahaan \\
Budi Pekerti/ Pengembangan Karakter & Referensi \\
& Pendidikan \\
\hline
\end{tabular}

\section{○ Percetakan}

PT Balai Pustaka (Persero) dapat melayani pence takan, mencakup jasa cetak sekuritas dan cetak umum. Jasa cetak sekuritas mencakup penceta kan dokumen sekuritas, surat berharga antara lain: Buku Nikah, Buku Akta Nikah, Sertifikat Tanah, Dokumen Ekspor, Soal Ujian Nasional (UN),

Sertifikat Ijazah Pendidikan atau Lembaga Profesi, Tanda Kelulusan dari berbagai institusi pendidi kan dalam negeri, Tiket Penerbangan, Dokumen Perbankan dan Asuransi seperti: Cek, Bilyet Giro, Polis Asuransi, Dokumen, Surat Berharga, Serti fikat, dan Formulir. Jasa Cetak Umum meliputi cetak buku, Agenda, Kalender, Annual Report, Brosur, Flyer dan jasa cetak lainnya.

\section{○ Multimedia}

Untuk menunjang upaya pelestarian dan pengembangan budaya, Balai Pustaka juga mengembangkan usaha multimedia. Hal tersebut sejalan dengan cepatnya perkembangan budaya global akibat kemajuan teknologi yang pesat. Beberapa usaha tersebut adalah:

- Serial Televisi

1. Animasi:

Pada era digital saat ini, animasi adalah salah satu media penyampaian gagasan yang paling efektif. Mengingat, Balai Pustaka memiliki content fiksi maupun non fiksi yang banyak dan beragam, maka kami merasa perlu merintis program edukasi yang dikemas secara animasi.

2. Timun Emas

3. Lutung Kasarung

- Bp e-store, Toko buku pintar dalam platform android, IOS, Windows

- Edutab TM, Tablet Pendidikan

\section{○ Manajemen Literasi}

TBM (Taman Bacaan Masyarakat) atau TBK (Taman Bacaan Keliling) pada dasarnya mengantarkan buku menjadi media bagi masyarakat untuk menuju kondisi yang lebih sejahtera.

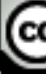

Ciptaan disebarluaskan di bawah Lisensi Creative Commons Atribusi 4.0 Internasional. 
TBM/TBK bertujuan untuk Menumbuhkan minat baca masyarakat di sekitar lokasi TBM/TBK, Meningkatkan ke mampuan literasi masyarakat, mendorong minat kewirausahaan masyarakat, menumbuhkan kemampuan untuk mengelola sumber daya yang dimiliki, dan menumbuhkan wawasan kebangsaan masyarakat.

Manajemen Literasi melingkupi TBM (Taman Bacaan Masyarakat), TBS (Taman Bacaan Sekolah), TBK (Taman Bacaan Keliling), Mobil Pintar, Perahu Pintar, Motor Pintar, Pelatihan menulis, dan pelatihan pengelolaan perpustakaan

\section{METODE DAN HASIL}

Data yang diperlukan terkait dengan penelitian ini adalah berupa laporan keuangan perusahaan. Data yang diambil adalah data sekunder meliputi; aktiva lancar, total aktiva, hutang lancar, total hutang, total modal sendiri, penjualan bersih dan laba bersih pada tahun 2011 sampai dengan tahun 2017. Dan data yang akan diolah adalah sebagai berikut

Tabel 1

Data Neraca Keuangan

PT Balai Pustaka (Persero)

Periode 2011-2017

\begin{tabular}{|c|c|c|c|c|c|c|c|}
\hline \multicolumn{8}{|c|}{$(\mathbf{R p})$} \\
\hline KET & 2011 & 2012 & 2013 & 2014 & 2015 & 2016 & 2017 \\
\hline $\begin{array}{l}\text { Aktiva } \\
\text { Lancar }\end{array}$ & $101,556,995,473$ & $70,620,535,170$ & $69,159,109,690$ & $96,362,370,915$ & $74,733,838,862$ & $77,011,118,310$ & $108,507,232,424$ \\
\hline $\begin{array}{l}\text { Total } \\
\text { Aktiva }\end{array}$ & $111,190,643,610$ & $82,007,315,616$ & $83,563,155,237$ & $111,400,898,977$ & $121,850,681,630$ & $101,876,139,662$ & $282,313,931,664$ \\
\hline $\begin{array}{l}\text { Utang } \\
\text { Lancar }\end{array}$ & $232,865,245,701$ & $231,275,027,197$ & $105,133,687,427$ & $140,915,677,111$ & $128,196,708,232$ & $124,212,514,329$ & $132,098,860,413$ \\
\hline $\begin{array}{l}\text { Total } \\
\text { Utang } \\
\end{array}$ & $235,876,464,206$ & $233,835,899,539$ & $107,698,164,248$ & $143,997,009,401$ & $133,414,569,643$ & $130,031,277,365$ & $168,406,497,118$ \\
\hline $\begin{array}{l}\text { Total } \\
\text { Ekuitas } \\
\end{array}$ & $(124,685,820,596)$ & $(151,828,583,923)$ & $(24,135,009,011)$ & $(32,596,110,424)$ & $(11,563,888,013)$ & $(28,155,137,703)$ & $113,907,434,546$ \\
\hline $\begin{array}{l}\text { Penjualan } \\
\text { Bersih }\end{array}$ & $82,090,303,899$ & $56,495,374,923$ & $20,148,117,716$ & $73,652,777,166$ & $19,165,363,519$ & $23,070,221,717$ & $48,183,323,166$ \\
\hline EBIT & $(13,241,455,789)$ & $(29,005,183,470)$ & $133,460,224,211$ & $(7,028,861,743)$ & $(11,576,215,829)$ & $4,757,987,124$ & $4,132,253,602$ \\
\hline $\begin{array}{l}\text { Laba } \\
\text { Bersih }\end{array}$ & $(13,241,455,789)$ & $27,142,763,327$ & $135,062,784,534$ & $8,461,101,413$ & $11,411,463,272$ & $5,912,912,830$ & $3,164,527,802$ \\
\hline
\end{tabular}

Sumber: Laporan Keuangan PT Balai Pustaka (Persero)

Teknik analisa yang digunakan dalam mengolah data adalah analisa rasio keuangan seperti yang dimaksud dalam Surat Keputusan Menteri BUMN Nomor KEP-100/MBU/2002, yang terdiri dari:

- $\quad$ ROE $=\frac{\text { Laba Setelah Pajak }}{\text { Modal Sendiri }}$ X 100\%

- $\quad$ ROI $=\frac{\text { EBIT }+ \text { Penyusutan }}{\text { Capital Employed }} X 100 \%$

- Cash Ratio $=\frac{\text { Kas+Bank+Surat Berharga Jangka Pendek }}{\text { Current Liabilities }} X 100 \%$

- Current Ratio $=\frac{\text { Current Asset }}{\text { Current Liabilities }} X 100 \%$

- Capital Periods $($ CP $)=\frac{\text { Total Piutang Usaha }}{\text { Total Pendapatan Usaha }} X 365$ hari

- Perputaran Persediaan $(P P)=\frac{\text { Total Persediaan }}{\text { Total Pendapatan Usaha }} X 365$ hari

- Perputaran Total Asset $($ TATO $)=\frac{\text { Total Pendapatan }}{\text { Capital Employed }}$ 100\%

- Total Modal Sendiri (TMS) terhadap (TA) Total Asset $=\frac{\text { Total Modal Sendiri }}{\text { Total Asset }}$ X00\%

Ciptaan disebarluaskan di bawah Lisensi Creative Commons Atribusi 4.0 Internasional. 
Tabel 2

ROE PT Balai Pustaka (Persero)

Periode 2011-2017

\begin{tabular}{|c|c|c|c|c|}
\hline \multirow{2}{*}{ TAHUN } & \multirow{2}{*}{$\begin{array}{c}\text { Laba Setelah Pajak } \\
\text { (Rp) }\end{array}$} & \multirow{2}{*}{$\begin{array}{l}\text { Modal Sendiri } \\
\text { (Rp) }\end{array}$} & ROE & \multirow{2}{*}{$100 \%$} \\
\hline & & & Laba Setelah Pajak : Modal sendiri & \\
\hline 2011 & $(13,241,455,789)$ & $(124,685,820,596)$ & 0.10619857 & 10.62 \\
\hline 2012 & $27,142,763,327$ & $(151,828,583,923)$ & -0.17877242 & -17.88 \\
\hline 2013 & $135,062,784,534$ & $(24,135,009,011)$ & -5.596135658 & -559.61 \\
\hline 2014 & $8,461,101,413$ & $(32,596,110,424)$ & -0.259573958 & -25.96 \\
\hline 2015 & $11,411,463,272$ & $(11,563,888,013)$ & -0.986818902 & -98.68 \\
\hline 2016 & $5,912,912,830$ & $(28,155,137,703)$ & -0.21001186 & -21.00 \\
\hline 2017 & $3,164,527,802$ & $113,907,434,546$ & 0.027781574 & 2.78 \\
\hline
\end{tabular}

Sumber: Data diolah

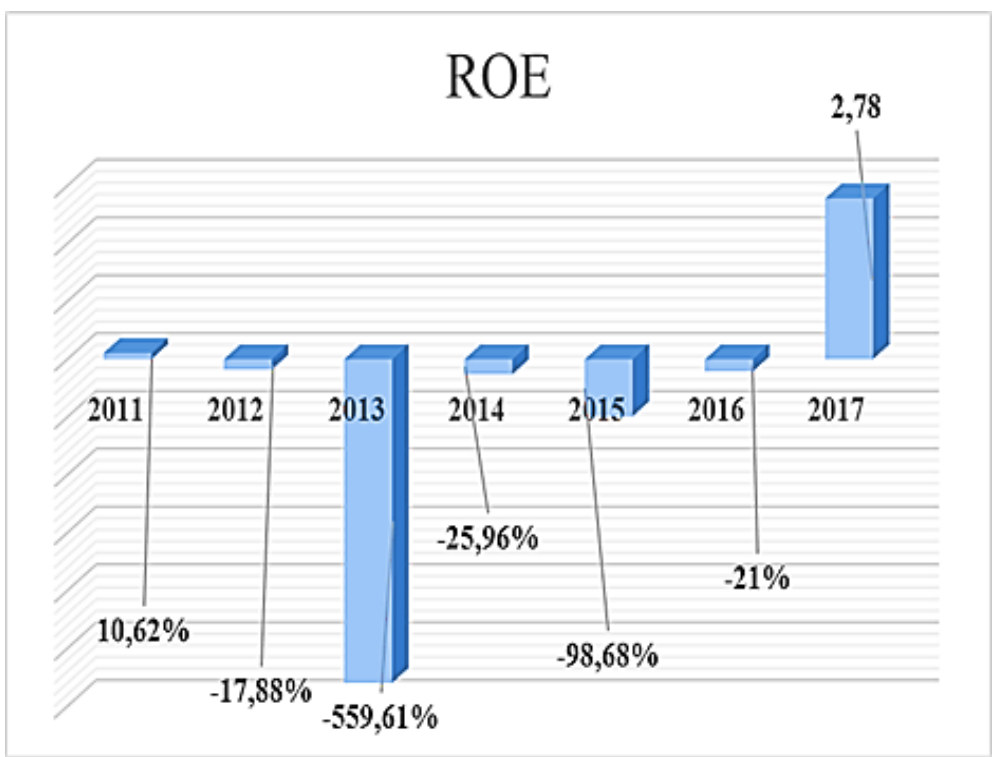

Berdasarkan hasil perhitungan tersebut diatas memperlihatkan bahwa ROE (Return On Equity) PT Balai Pustaka (Persero) dari tahun 2011 berfluktuatif dan dalam kondisi negatif Namun di tahun 2017 menunjukkan perbaikan menjadi kondisi positip, hal ini disebabkan karena adanya perbaikan disektor laba dan modal sendiri.

Tabel 3

ROI PT Balai Pustaka (Persero)

Periode 2011-2017

\begin{tabular}{|lc|c|c|}
\hline \multicolumn{2}{|c|}{ Ebit + Penyusutan } & $\begin{array}{c}\text { Hasil Dari Ebit + Penyusutan : } \\
\text { Capital Employed }\end{array}$ & Hasil di bagi di X 100\% \\
\hline $\mathrm{Rp}$ & $(13,241,455,789)$ & -0.11909 & -11.91 \\
\hline $\mathrm{Rp}$ & $(29,005,183,470)$ & -0.3537 & -35.37 \\
\hline $\mathrm{Rp}$ & $133,460,224,211$ & 1.5971 & 159.71 \\
\hline $\mathrm{Rp}$ & $(7,028,861,743)$ & -0.0631 & -6.31 \\
\hline
\end{tabular}

\footnotetext{
Ciptaan disebarluaskan di bawah Lisensi Creative Commons Atribusi 4.0 Internasional.
} 


\begin{tabular}{|lr|c|c|}
\hline $\mathrm{Rp}$ & $(11,576,215,829)$ & -0.0950 & -9.50 \\
\hline $\mathrm{Rp}$ & $4,757,987,124$ & 0.0467 & 4.67 \\
\hline $\mathrm{Rp}$ & $4,132,253,602$ & 0.0146 & 1.46 \\
\hline
\end{tabular}

Sumber: Data diolah

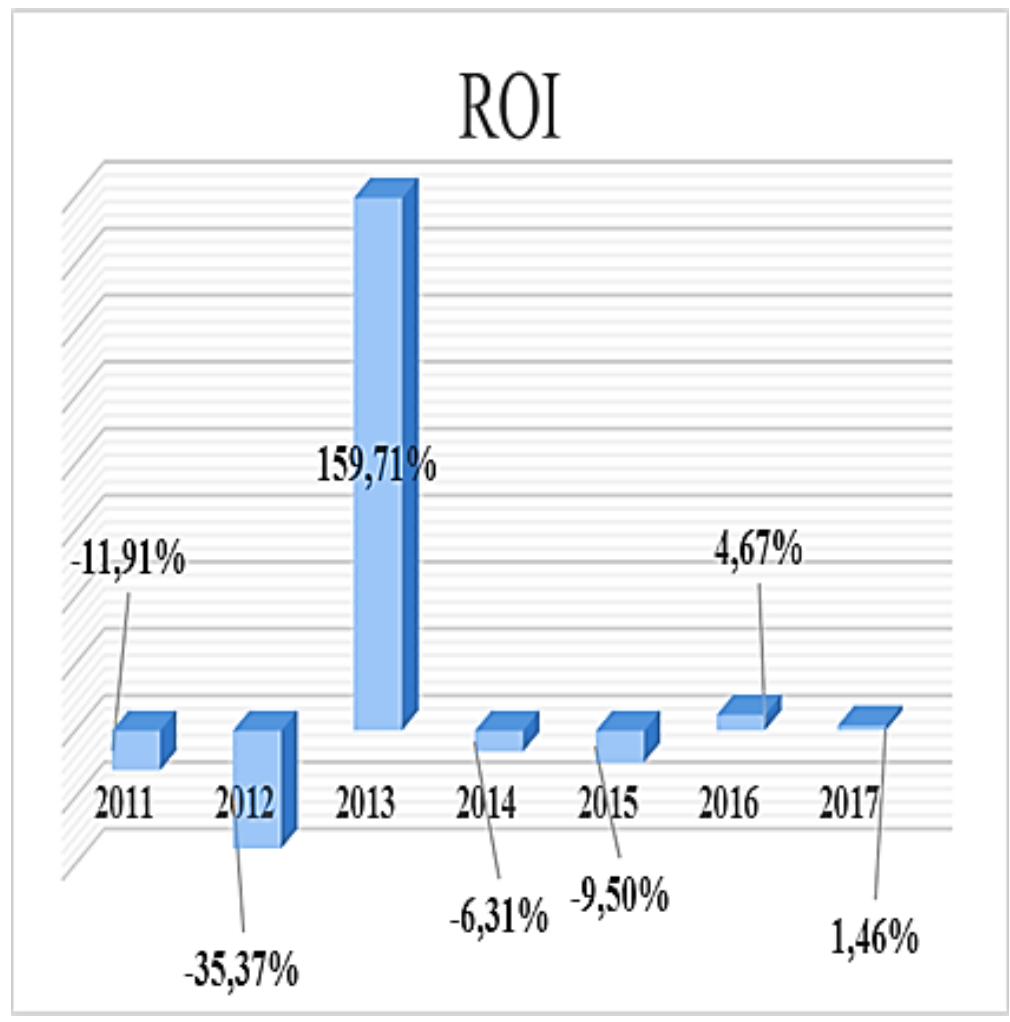

Berdasarkan hasil perhitungan tersebut diatas memperlihatkan bahwa ROI PT Balai Pustaka (Persero) juga berfluktuatif , ditahun 2013 memperlihatkan nilai positip (159,71\%) karena adanya peningkatan EBIT yang cukup significant karena adanya Pendapatan lain-lain Rp. 173,816,889,067. Sedangkan EBIT ditahun 2016, 2017 menunjukkan nilai positif walaupun kecil $(4,67 \%, 1,46 \%)$

Tabel 4

Cash Ratio PT Balai Pustaka (Persero)

Periode 2011-2017

\begin{tabular}{|l|c|c|c|c|}
\hline \multicolumn{9}{|c|}{ CASH RATIO } & \multirow{2}{*}{ 100\% } \\
\cline { 1 - 4 } TAHUN & Kas dan Setara & Hutang Lancar & \multicolumn{2}{|c|}{ Cash Ratio } \\
\cline { 3 - 5 } & $(\mathbf{R p})$ & $(\mathbf{R p})$ & $\begin{array}{l}\text { Kas dan Setara : Hutang } \\
\text { Lancar }\end{array}$ & \\
\hline 2011 & $12,417,400,560$ & $232,865,245,701$ & 0.0533 & 5.33 \\
\hline 2012 & $4,919,994,235$ & $231,275,027,197$ & 0.0213 & 2.13 \\
\hline 2013 & $6,916,216,467$ & $105,133,687,427$ & 0.0658 & 6.58 \\
\hline 2014 & $14,686,226,749$ & $140,915,677,111$ & 0.1042 & 10.42 \\
\hline 2015 & $2,397,102,217$ & $128,196,708,232$ & 0.0187 & 1.87 \\
\hline 2016 & $1,673,344,467$ & $124,212,514,329$ & 0.0135 & 4.35 \\
\hline 2017 & $5,292,216,142$ & $132,098,860,413$ & 0.0401 & 4.01 \\
\hline
\end{tabular}

Sumber: Data diolah

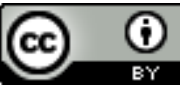

Ciptaan disebarluaskan di bawah Lisensi Creative Commons Atribusi 4.0 Internasional. 


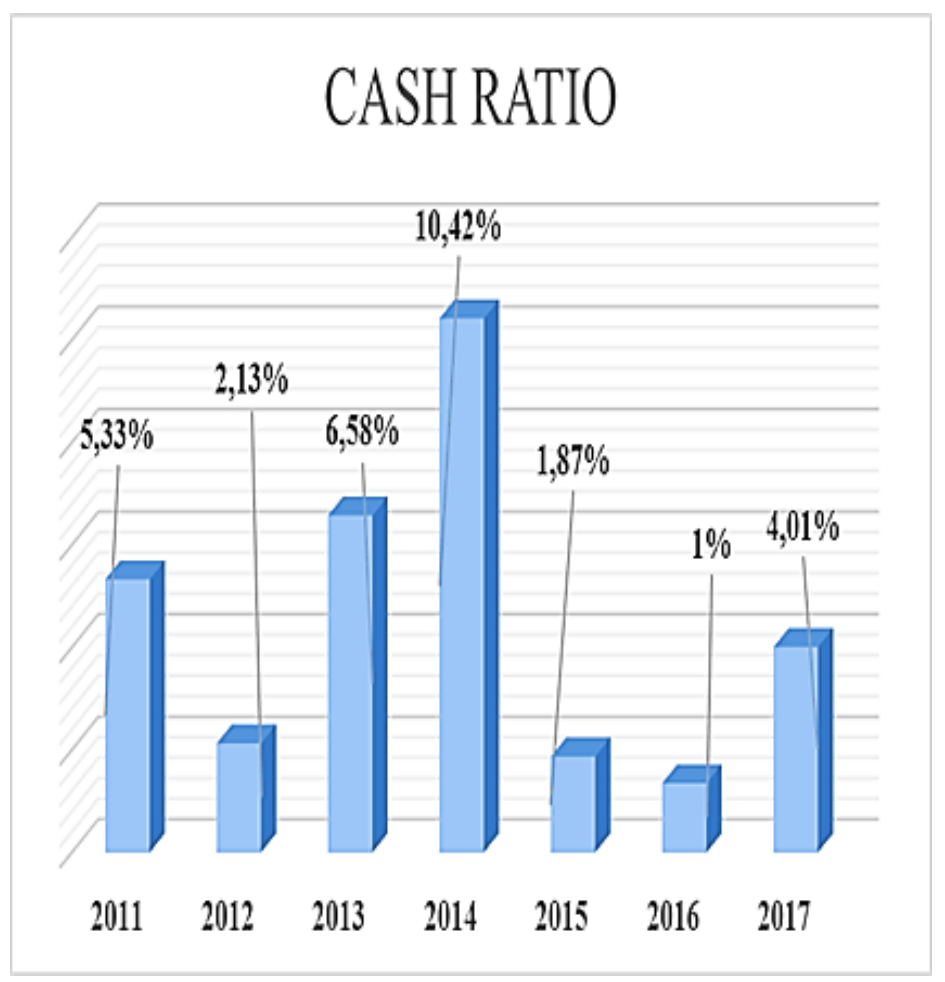

Berdasarkan hasil perhitungan tersebut diatas memperlihatkan bahwa kas PT Balai Pustaka (Persero) tertinggi dicapai pada tahun 2014 dengan nilai $10.42 \%$. Namun demikian secara keseluruhan nilai rasio kas belum dapat dikatakan baik karena nilainya masih dibawah $100 \%$, yang artinya bahwa kas perusahaan belum mampu nutuk menutup hutang lancarnya.

Tabel 5

Current Ratio PT Balai Pustaka (Persero) Periode 2011-2017

\begin{tabular}{|c|c|c|c|c|}
\hline \multicolumn{5}{|c|}{ CURRENT RATIO } \\
\hline \multirow[t]{2}{*}{ TAHUN } & \multirow{2}{*}{$\begin{array}{c}\text { Aktiva Lancar } \\
\text { (Rp) }\end{array}$} & \multirow{2}{*}{$\begin{array}{c}\text { Hutang Lancar } \\
\text { (Rp) }\end{array}$} & $\begin{array}{r}\text { Cash Ratio } \\
\end{array}$ & \multirow[t]{2}{*}{$100 \%$} \\
\hline & & & Aktiva Lancar : Hutang Lancar & \\
\hline 2011 & $101,556,995,473$ & $232,865,245,701$ & 0.4361 & 43.61 \\
\hline 2012 & $70,620,535,170$ & $231,275,027,197$ & 0.3054 & 30.54 \\
\hline 2013 & $69,159,109,690$ & $105,133,687,427$ & 0.6578 & 65.78 \\
\hline 2014 & $96,362,370,915$ & $140,915,677,111$ & 0.6838 & 68.38 \\
\hline 2015 & $74,733,838,862$ & $128,196,708,232$ & 0.5830 & 58.30 \\
\hline 2016 & $77,011,118,310$ & $124,212,514,329$ & 0.6200 & 62.00 \\
\hline 2017 & $108,507,232,424$ & $132,098,860,413$ & 0.8214 & 82.14 \\
\hline
\end{tabular}

Sumber: Data diolah

Ciptaan disebarluaskan di bawah Lisensi Creative Commons Atribusi 4.0 Internasional. 
Berdasarkan hasil perhitungan diatas memperlihatkan bahwa current ratio PT Balai Pustaka (Persero) belum menunjukkan angka yang baik, masih dibawah $100 \%$, yang mengindikasikan bahwa asset lancarnya belum mampu untuk menutup hutang lancarnya. Di tahun 2017 current ratio menunjukkkan nilai yang relatif lebih baik dari tahun sebelumnnya mendekati angka $100 \%$. Peningkatan ini disebabkan adanya peningkatan dalam current assetnya.

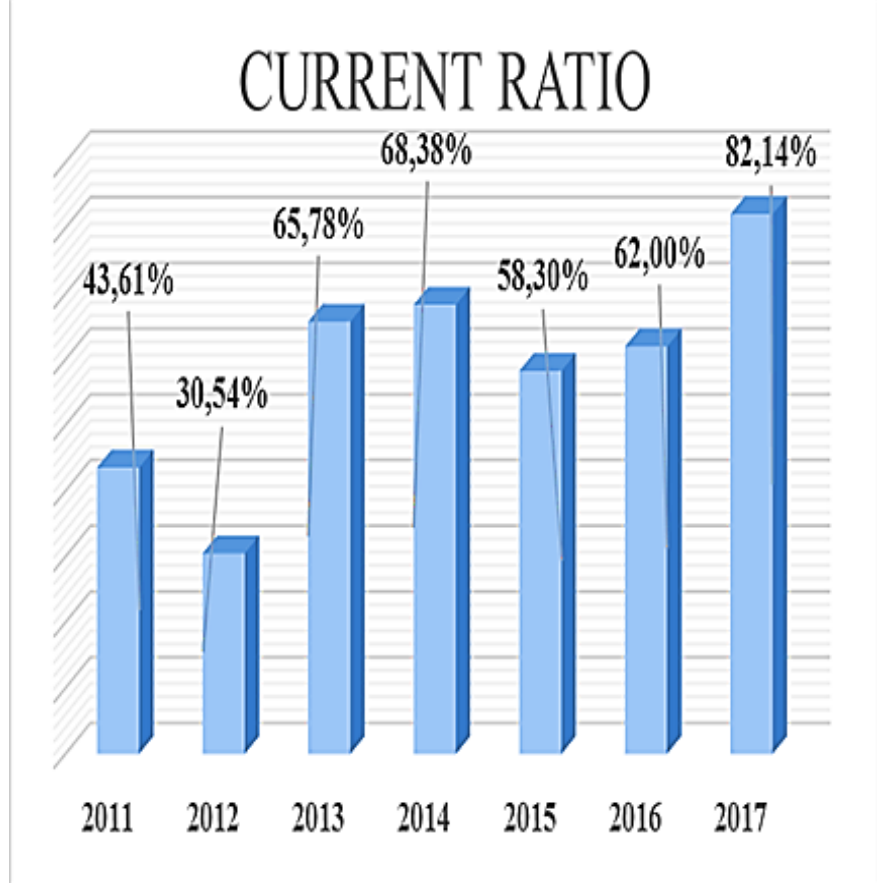

Tabel 6

Collection Periods (CP)

PT Balai Pustaka (Persero)

Periode 2011-2017

\begin{tabular}{|c|c|c|c|c|}
\hline \multicolumn{5}{|c|}{ COLLECTION PERIODS (CP) } \\
\hline \multirow[t]{2}{*}{ TAHUN } & \multirow{2}{*}{$\begin{array}{c}\text { Piutang Usaha } \\
\text { (Rp) }\end{array}$} & \multirow{2}{*}{$\begin{array}{c}\text { Pendapatan Usaha } \\
\text { (Rp) }\end{array}$} & $\mathbf{C P}$ & hari \\
\hline & & & Piutang Usaha : Pendapatan Usaha & \\
\hline 201 & $65,503,758,46$ & $9 \quad 82,090,303,89$ & 0.79795 & 291.3 \\
\hline 201 & $46,620,669,21$ & $56,495,374,92$ & 0.8252121 & 301.2 \\
\hline 201 & $35,201,135,40$ & $20,148,117,71$ & 1.7471178 & 637.7 \\
\hline $4 \quad 201$ & $56,894,718,02$ & $73,652,777,16$ & 0.7724721 & 282.0 \\
\hline $5 \quad 201$ & $50,215,966,41$ & $19,165,363,51$ & 2.6201416 & 956.4 \\
\hline $6 \quad 201$ & $54,134,465,16$ & $23,070,221,71$ & 2.3465082 & 856.5 \\
\hline $\begin{array}{ll}701 \\
7\end{array}$ & $63,570,312,78$ & $48,183,323,16$ & 1.3193426 & 481.6 \\
\hline
\end{tabular}

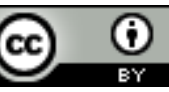

Ciptaan disebarluaskan di bawah Lisensi Creative Commons Atribusi 4.0 Internasional. 
Sumber: Data diolah

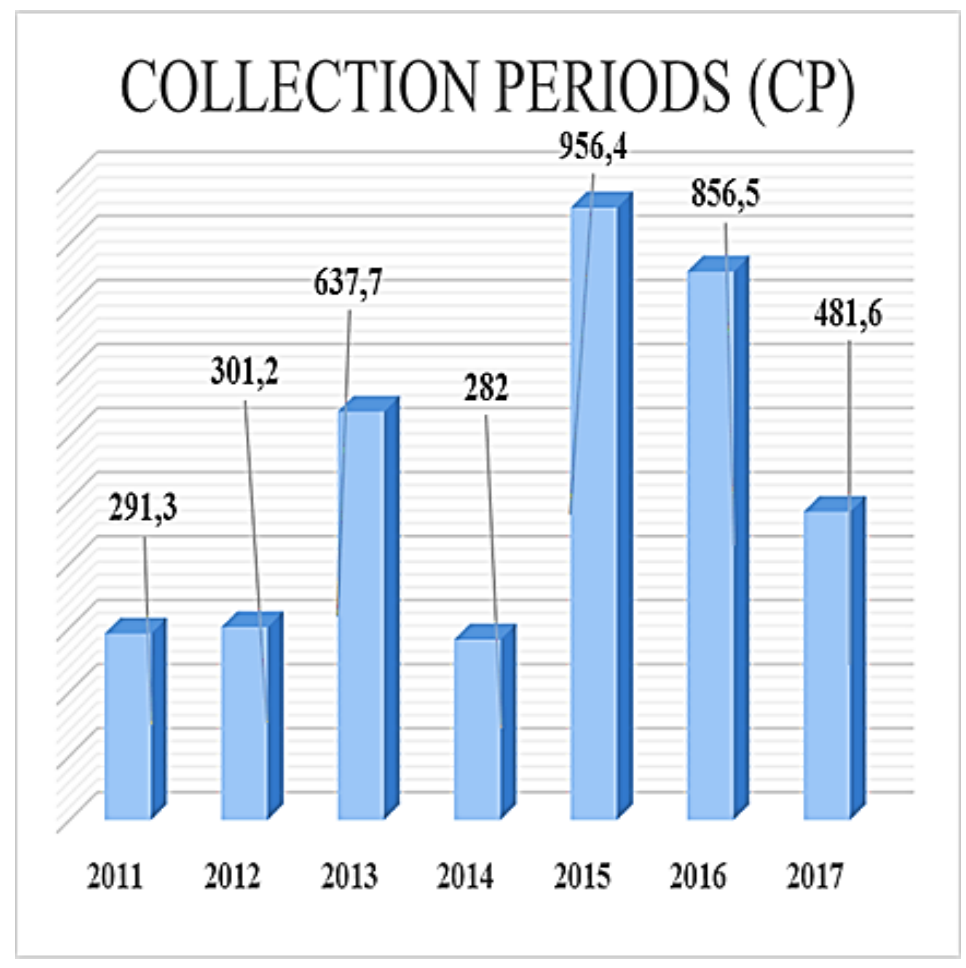

Berdasarkan perhitungan diatas menunjukkan collection period PT Balai Pustaka (Persero) mencapai waktu diatas 100 hari ini menunjukkan bahwa banyak dana tertanam di piutang. Tahun 2015 dan tahun 2016 , collection periods mencapai waktu 956, 4 hari dan 856, 5 hari, hal ini terjadi karena secara signifikan jumlah piutang lebih besar dari pada jumlah penjualan/pendapatan.

Tabel 7

Perputaran Persediaan (PP)

PT Balai Pustaka (Persero)

Periode 2011-2017

\begin{tabular}{|c|c|c|c|c|}
\hline \multicolumn{5}{|c|}{ PERPUTARAN PERSEDIAAN (PP) } \\
\hline \multirow[t]{2}{*}{ TAHUN } & \multirow{2}{*}{$\begin{array}{c}\text { Persediaan } \\
(\mathrm{Rp})\end{array}$} & \multirow{2}{*}{$\begin{array}{c}\text { Pendapatan Usaha } \\
(\mathrm{Rp}) \\
\end{array}$} & $\mathbf{P P}$ & \multirow[t]{2}{*}{ hari } \\
\hline & & & Persediaan : Pendapatan Usaha & \\
\hline 2011 & $13,509,016,088$ & $82,090,303,899$ & 0.16456287 & 60.07 \\
\hline 2012 & $8,534,815,356$ & $56,495,374,923$ & 0.151071046 & 55.14 \\
\hline 2013 & $6,681,539,750$ & $20,148,117,716$ & 0.33162104 & 121.04 \\
\hline 2014 & $10,732,733,124$ & $73,652,777,166$ & 0.145720685 & 53.19 \\
\hline 2015 & $13,012,687,151$ & $19,165,363,519$ & 0.678968971 & 247.82 \\
\hline 2016 & $13,158,085,009$ & $23,070,221,717$ & 0.570349309 & 208.18 \\
\hline 2017 & $13,593,283,404$ & $48,183,323,166$ & 0.282115938 & 102.97 \\
\hline
\end{tabular}

Sumber: Data diolah

Ciptaan disebarluaskan di bawah Lisensi Creative Commons Atribusi 4.0 Internasional. 


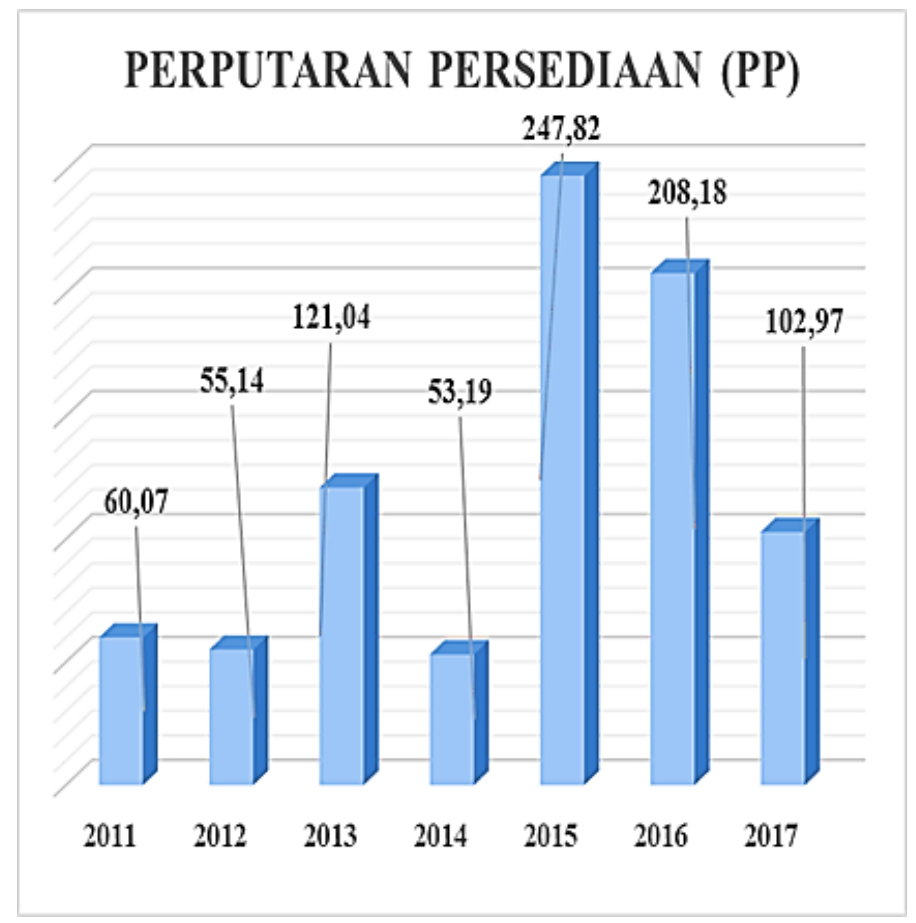

Berdasarkan perhitungan diatas bahwa pada tahun 2011, 2012, dan 2014 tingkat perputaran persediaan cukup tinggi yang diindikasikan dengan lamanya waktu persediaan disimpan di gudang kurang dari 100 hari Sedangkan di tahun 2013, 1015, 2016, 2017 perputaran persediaan mencapai waktu lebih dari 100 hari hal ini terjadi karena jumlah persediaan yang ada tidak sebanding dengan jumlah pendapatan

Tabel 8

Total Asset Turn Over (TATO)

PT Balai Pustaka (Persero)

Periode 2011-2017

\begin{tabular}{|c|c|c|c|c|}
\hline \multicolumn{5}{|c|}{ TOTAL ASSET TURN OVER (TATO) } \\
\hline \multirow{2}{*}{ TAHUN } & Total Pendapatan & Capital Employed & TATO & \multirow{1}{*}{$\mathbf{1 0 0 \%}$} \\
\cline { 3 - 4 } & $(\mathrm{Rp})$ & $(\mathrm{Rp})$ & $\begin{array}{l}\text { Total Pendapatan : } \\
\text { Capital Employed }\end{array}$ & \\
\hline 2011 & $82,090,303,899$ & $111,190,643,610$ & 0.7383 & 73.83 \\
\hline 2012 & $56,495,374,923$ & $82,007,315,616$ & 0.6889 & 68.89 \\
\hline 2013 & $20,148,117,716$ & $83,563,155,237$ & 0.2411 & 24.11 \\
\hline 2014 & $73,652,777,166$ & $111,400,898,977$ & 0.6612 & 66.12 \\
\hline 2015 & $19,165,363,519$ & $121,850,681,630$ & 0.1573 & 15.73 \\
\hline 2016 & $23,070,221,717$ & $101,876,139,662$ & 0.2265 & 22.65 \\
\hline 2017 & $48,183,323,166$ & $282,313,931,664$ & 0.1707 & 17.07 \\
\hline
\end{tabular}

Sumber: Data diolah 


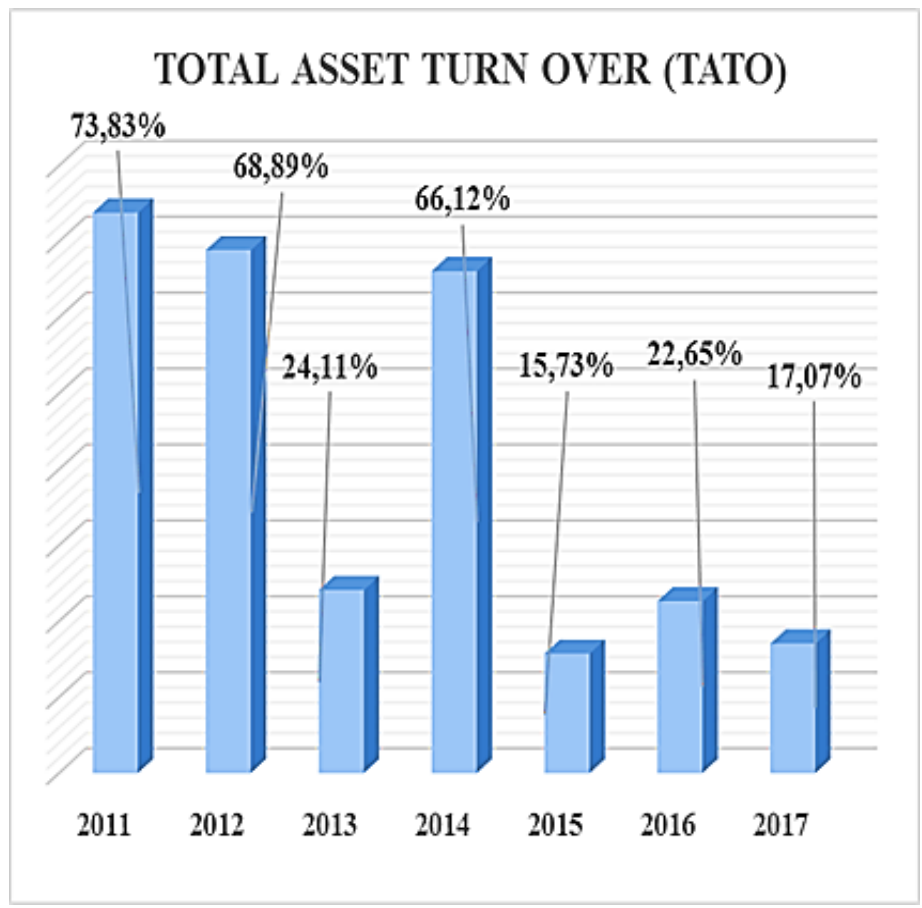

Berdasarkan hasil perhitungan tersebut diatas memperlihatkan bahwa TATO dari tahun ke tahun cenderung menurun. TATO tertinggi dicapai tahun 2011 (73,83\%), $2012(68,89 \%), 2014(66,12 \%)$ ini mengindikasikan bahwa perputaran total asset dapat menghasilkan pendapatan yang relative sebanding dengan total assetnya.

Tabel 9

Total Modal Sendiri Terhadap Total Asset (TMS terhadap TA) PT Balai Pustaka (Persero)

Periode 2011-2017

\begin{tabular}{|c|c|c|c|r|}
\hline \multicolumn{5}{|c|}{ TOTAL MODAL SENDIRI TERHADAP TOTAL ASSET (TMS Terhadap TA) } \\
\cline { 1 - 3 } TAHUN & Modal Sendiri & Total Asset & \multirow{2}{*}{$\mathbf{1 0 0 \%}$} \\
\cline { 4 - 5 } & $(\mathbf{R p})$ & $(\mathbf{R p})$ & TMS thd TA & \\
\hline 2011 & $(124,685,820,596)$ & $111,190,643,610$ & -1.1214 & -112.14 \\
\hline 2012 & $(151,828,583,923)$ & $82,007,315,616$ & -1.8514 & -185.14 \\
\hline 2013 & $(24,135,009,011)$ & $83,563,155,237$ & -0.2888 & -28.88 \\
\hline 2014 & $(32,596,110,424)$ & $111,400,898,977$ & -0.2926 & -9.49 \\
\hline 2015 & $(11,563,888,013)$ & $121,850,681,630$ & -0.0949 & -27.64 \\
\hline 2016 & $(28,155,137,703)$ & $101,876,139,662$ & -0.2764 & 40.35 \\
\hline 2017 & $113,907,434,546$ & $282,313,931,664$ & 0.4035 & \\
\hline
\end{tabular}

Sumber: Data diolah 


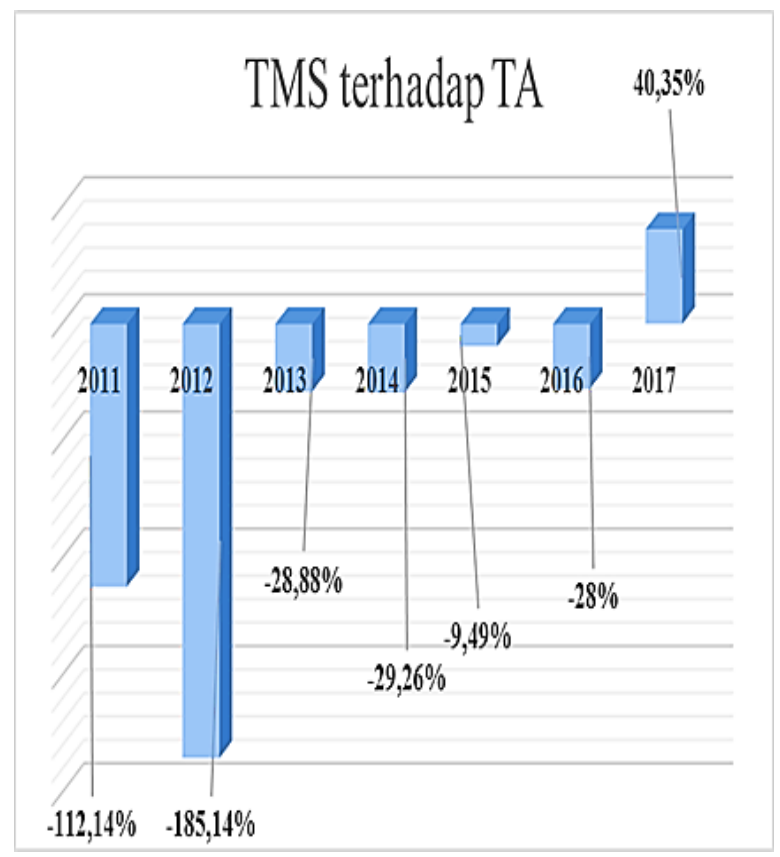

Data diatas menunjukan bahwa rasio modal sendiri PT Balai Pustaka (Persero) menunjukkan nilai negative karena modal sendiri mempunyai nilai negative. Di tahun 2017 rasio modal sendiri mencapai nilai positip (40,35\%) karena adanya peningkatan dalam jumlah modal sendiri .

Tabel 10

Rasio Keuangan PT Balai Pustaka (Persero)

Periode 2011-2017

\begin{tabular}{|c|l|c|c|c|c|c|c|c|}
\hline \multirow{2}{*}{ NO } & \multirow{2}{*}{ INDIKATOR } & \multicolumn{7}{c|}{ PT. BALAI PUSTAKA (PERSERO) } \\
\cline { 3 - 9 } & & $\mathbf{2 0 1 1}$ & $\mathbf{2 0 1 2}$ & $\mathbf{2 0 1 3}$ & $\mathbf{2 0 1 4}$ & $\mathbf{2 0 1 5}$ & $\mathbf{2 0 1 6}$ & $\mathbf{2 0 1 7}$ \\
\cline { 3 - 9 } & & RASIO & RASIO & RASIO & RASIO & RASIO & RASIO & RASIO \\
\hline \multirow{2}{*}{1} & $\begin{array}{l}\text { Imbalan Kepada Pemegang } \\
\text { Saham/ROE (\%) }\end{array}$ & 10,62 & $-17,88$ & $-559,61$ & $-25,96$ & $-98,68$ & -21 & 2,78 \\
\hline 2 & Imbalan Investasi/ROI (\%) & $-11,91$ & $-35,37$ & 159,71 & $-6,31$ & $-9,5$ & 4,67 & 1,46 \\
\hline 3 & Rasio Kas/Cash Ratio (\%) & 5,33 & 2,19 & 6,58 & 10,42 & 1,87 & 1,35 & 4,01 \\
\hline 4 & Rasio Lancar/Current Ratio (\%) & 43,61 & 30,54 & 65,78 & 68,38 & 58,3 & 62 & 82,14 \\
\hline 5 & Collection Periods (Hari) & 291,3 & 301,2 & 637,7 & 282,0 & 956,4 & 856,5 & 481,6 \\
\hline 6 & Perputaran Persediaan/PP (Hari) & 60,07 & 55,14 & 121,04 & 53,19 & 247,82 & 208,18 & 102,97 \\
\hline 7 & Perputaran Total Asset/TATO (\%) & 73,83 & 68,89 & 24,11 & 66,12 & 15,73 & 22,65 & 17,07 \\
\hline 8 & $\begin{array}{l}\text { Rasio total modal sendiri (TMS) } \\
\text { terhadap total asset (TA) (\%) }\end{array}$ & $-112,14$ & $-185,14$ & $-28,88$ & $-29,26$ & $-9,49$ & $-27,64$ & \multirow{2}{*}{40,35} \\
\hline
\end{tabular}

Sumber: Data diolah

Ciptaan disebarluaskan di bawah Lisensi Creative Commons Atribusi 4.0 Internasional. 
Tabel 11

Tingkat Kesehatan Kinerja Keuangan PT Balai Pustaka (Persero)

Periode 2011-2017

\begin{tabular}{|c|c|c|c|c|c|c|c|c|}
\hline \multirow{3}{*}{ NO } & \multirow{3}{*}{ INDIKATOR } & \multicolumn{7}{|c|}{ PT. BALAI PUSTAKA (PERSERO) } \\
\hline & & 2011 & 2012 & 2013 & 2014 & 2015 & 2016 & 2017 \\
\hline & & BOBOT & BOBOT & BOBOT & BOBOT & BOBOT & BOBOT & BOBOT \\
\hline 1 & $\begin{array}{l}\text { Imbalan Kepada Pemegang } \\
\text { Saham (ROE) }\end{array}$ & 14 & 0 & 0 & 0 & 0 & 0 & 5,5 \\
\hline 2 & Imbalan Investasi (ROI) & 0 & 0 & 15 & 0 & 0 & 4 & 3 \\
\hline 3 & Rasio Kas/Cash Ratio & 1 & 0 & 1 & 2 & 0 & 0 & 0 \\
\hline 4 & Rasio Lancar/Current Ratio & 0 & 0 & 0 & 0 & 0 & 0 & 0 \\
\hline 5 & Collection Periods & 0,6 & 0 & 0 & 0,6 & 0 & 0 & 0 \\
\hline 6 & Perputaran Persediaan (PP) & 4,5 & 5 & 3,5 & 5 & 1,2 & 2,4 & 4 \\
\hline 7 & $\begin{array}{l}\text { Perputaran Total Asset } \\
\text { (TATO) }\end{array}$ & 3 & 3 & 2 & 3 & 1,5 & 2 & 1,5 \\
\hline 8 & $\begin{array}{l}\text { Rasio total modal sendiri } \\
\text { (TMS) terhadap total asset } \\
\text { (TA) }\end{array}$ & 0 & 0 & 0 & 0 & 0 & 0 & 9 \\
\hline \multicolumn{2}{|c|}{ AKUMULASI BOBOT } & 23,1 & 8 & 21,5 & 10,6 & 2,7 & 8,4 & 23 \\
\hline \multicolumn{2}{|c|}{$\begin{array}{l}\text { TOTAL SKOR (SK Men BUMN } \\
\text { Nomor:KEP-100/MBU/2002) }\end{array}$} & $\mathbf{7 0}$ & $\mathbf{7 0}$ & 70 & 70 & 70 & 70 & 70 \\
\hline \multicolumn{2}{|c|}{$\begin{array}{l}\text { HASIL DARI AKUMULASI } \\
\text { BOBOT }(: 70 \times 100)\end{array}$} & 33 & 11,43 & 30,71 & 15,14 & 3,85 & 12 & 32,85 \\
\hline \multicolumn{2}{|r|}{ TINGKAT KESEHATAN } & $\begin{array}{c}\text { kurang } \\
\text { sehat }\end{array}$ & $\begin{array}{l}\text { tidak } \\
\text { sehat }\end{array}$ & $\begin{array}{c}\text { kurang } \\
\text { sehat }\end{array}$ & $\begin{array}{l}\text { tidak } \\
\text { sehat }\end{array}$ & $\begin{array}{l}\text { tidak } \\
\text { sehat }\end{array}$ & $\begin{array}{l}\text { tidak } \\
\text { sehat }\end{array}$ & $\begin{array}{c}\text { kurang } \\
\text { sehat }\end{array}$ \\
\hline \multicolumn{2}{|r|}{ KATEGORI } & B & C & B & C & C & C & B \\
\hline
\end{tabular}

Sumber: Data diolah

Berdasarkan tabel 4.10 dan 411 dapat dijelakan sebagai berikut:

1. ROE yang di peroleh PT Balai Pustaka (Persero) dari tahun 2011 bernilai positip (10,62\%) tahun 2012 , 2013, 2014, 2015, 2016 bernilai negatif. Tahun 2017 kembali bernilai positip (2,78\%). Peningkatan ini disebabkan karena pada tahun 2017 perusahaan memperoleh laba dan modal sendiri perusahaan sudah bernilai positip. Jika di hadapkan kepada standar penilaian berdasarkan SK Menteri BUMN nomor KEP 100/MBU/2002, bobot yang diberikan untuk penilaian ROE adalah tahun 2011 bobot 14, tahun 2012, 2013, 2014, 2016 bobot nilai 0 dan tahun 2017 bobot nilai 55.

2. ROI yang diperoleh PT Balai Pustaka (Persero) bernilai negatif kecuali di tahun 2013 (159,71\%), 2016 (4,67\%), 2017 (1,46\%). Jika dihadapkan kepada standar penilaian berdasarkan SK Menteri BUMN nomor KEP 100/ MBU/2002, bobot yang diberikan untuk penilaian ROI adalah 0, kecuali untuk tahun 2013 (15), tahun 2016 (4) dan tahun 2017 (3).

3. Rasio kas dari tahun 2011 sampai tahun 2017 cenderung berfluktuatif, posisi tertinggi dicapai tahun 2014 , menurun di tahun 2015, 2016 dan meningkat kembali di tahun 2017. Jika dihadapkan kepada standar penilaian berdasarkan SK Menteri BUMN nomor KEP 100/ MBU/2002, didapat bobot penilaian yang diberikan adalah 0, kecuali untuk tahun 2011 bobot yang diberikan 1, tahun 2013, 2014 masing-masing bobot 1 dan 2

4. Rasio lancar cenderung berfluktuatif dari 2011 sampai 2017 dan poisi terbaik dicapai di tahun 2017 $(82,14 \%)$, Namun demikian jika dihadapkan kepada penilaian berdasarkan SK Menteri BUMN nomor KEP 100/ MBU/2002, nilai-nilai mempunyai bobot 0 .

Ciptaan disebarluaskan di bawah Lisensi Creative Commons Atribusi 4.0 Internasional. 
5. Rasio pengumpulan piutang (collection periods) menunjukkan angka yang tidak baik, karena waktu yang digunakan untuk pengumpulan piutang sudah mencapai rata-rata 295 hari lebih. Ini mengindikasikan bahwa dana/uang perusahaan banyak tertanam dalam piutang. Jika dihadapkan kepada penilaian berdasarkan SK Menteri BUMN nomor KEP 100/MBU/2002, maka di dapatkan bobot 0, kecuali ditahun 2011 dan tahun 2014 masing-masing berbobot 0,6 .

6. Rasio Perputaran Persediaan menunjukkan angka yang berfluktuatif, kondisi yang terbaik ada di tahun 2011, 2012, 2014, karena capaian waktunya kurang dari 100 hari, ini menunjukkkan tingkat efektivitas persediaan dalam menghasilkan pendapatan. Bobot yang diberikan dalam perhitungan perputaran persediaan adalah tahun 2011, 2012, 2013, 2014, 2015, 2016, 2017 masing-masing 4,5; 5; 3,5; 5; 1,2; 2,4; 4.

7. Rasio perputaran total asset cenderung berfluktuatif menurun ditahun 2012,2013 , meningkat di tahun 2014 dan kembali menurun ditahun 2015, 2016, 2017. Bila di hadapkan ke penilaian berdasarkan SK Menteri BUMN nomor KEP 100/MBU/2002, maka bobot yang dicapai rata -rata 3 dan mempunyai nilai yang tinggi di tahun 2015 dan tahun 2017 yang mencapai bobot 15 .

8. Rasio modal sendiri terhadap total asset menunjukkan angka yang cenderung menurun, sehingga bobot yang diberikan ber nilai 0 , hanya di tahun 2017 nilai bobot mencapai nilai 9, hal ini disebabkan karena tahun 2017 modal sendiri sudah mencapai nilai positip.

9. Penjumlahan nilai bobot indicator yang digunakan mencapai nilai 23,1 (2011), 8 (2012), 21,5 (2013), 10,6 (2014), 27 (2015), 8,4 (2016), 23 (2017). Standart yang ditetapkan oleh SK Menteri BUMN nomor KEP 100/MBU/2002, akumulasi bobot indicator bernilai 70. Dengan demikian capaian akumulasi bobot yang dicapai adalah 33 (2011), 11,43 (2012), 30,71 (2013),15,14 (2014), 3,85 (2015), 12 (2016), 32,85 (2017). Dari milai akumulasi indicator bobot terlihat bahwa perusahaan dalam kondisi tidak sehat di tahun 2012, 2014, 2015, 2016. Sedangkan di tahun 2011, 2013, dan tahun 2017 perusahaan dalam kondisi kurang sehat.

10. Berdasarkan perhitungan di butir 9 maka dapat dijelaskan bahwa kinerja keuangan PT Balai Pustaka (Persero), sebelum dan sesudah merger masih memperlihatkan kondisi yang kurang sehat. Walaupun secara analisa kinerja keuangan di tahun 2017 sudah menunjukkan kondisi yang lebih baik, hal ini ditunjukkan ROE, ROI. Perbaikan ROE dan ROI karena modal sendiri dan total asset perusahaan mulai meningkat

dan bernilai positip.

\section{KESIMPULAN}

Penjumlahan nilai bobot indicator yang digunakan mencapai nilai 23,1 (2011), 8 (2012), 21,5 (2013), 10,6 (2014), 27 (2015), 8,4 (2016), 23 (2017). Standart yang ditetapkan oleh SK Menteri BUMN nomor KEP 100/MBU/2002, akumulasi bobot indicator bernilai 70. Dengan demikian capaian akumulasi bobot yang dicapai adalah 33 (2011), 11,43 (2012), 30,71 (2013),15,14 (2014), 3,85 (2015), 12 (2016), 32,85 (2017). Dari milai akumulasi indicator bobot terlihat bahwa perusahaan dalam kondisi tidak sehat di tahun 2012, 2014, 2015, 2016. Sedangkan di tahun 2011, 2013, dan tahun 2017 perusahaan dalam kondisi kurang sehat.

Berdasarkan perhitungan maka dapat dijelaskan bahwa kinerja keuangan PT Balai Pustaka (Persero), sebelum dan sesudah merger masih memperlihatkan kondisi yang kurang sehat. Walaupun secara analisa kinerja keuangan di tahun 2017 sudah menunjukkan kondisi yang lebih baik, hal ini ditunjukkan ROE, ROI. Perbaikan ROE dan ROI karena modal sendiri dan total asset perusahaan mulai meningkat dan bernilai positip.

\section{REFERENASI}

[1] Hitt, Michael, A, Jeffey, S, Harrison, Irlandia, D (terj.) (2002). Merger dan Akuisisi: Penduan Meraih Laba Bagi Para Pemegang Saham. Jilid 1, Edisi 1, Jakarta: Raja Grafindo Persada.

[2] Payamta, P dan Setiawan, D.S (2004). Analisis Pengaruh Merger dan Akuisis Terhadap Kinerja Perusahaan Publik di Indonesia. Riset Akuntansi Indonesia, Vol. 7 No. 3 (September).

[3] Selcuk, EA dan Yilmaz, AA (2011) Dampak Merger dan Akuisisi terhadap Kinerja Acquirer: Evidence from Turkey Business and Economics Journal, Volume 2011: BEJ- 22.

[4] Moin, M Abdul, A. (2003). Merger, Akuisisi dan Divestasi. Jilid 1. Yogyakarta: Ekonisia.

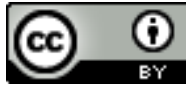

Ciptaan disebarluaskan di bawah Lisensi Creative Commons Atribusi 4.0 Internasional. 


\section{Journal of Information System, Applied, Management, Accounting and Research.}

http://journal.stmikjayakarta.ac.id/index.php/jisamar, jisamar@stmikjayakarta.ac.id , jisamar2017@gmail.com

e-ISSN: 2598-8719 (Online), p-ISSN: 2598-800 ( Printed), Vol. x No.x bulan xxxx 202x

[5] Brigham, B Eugene, F dan Joel, F Houston, H (2001). Manajemen Keuangan. Jilid2. Edisi 8. Jakarta: Erlangga.

[6] Ijazair TA (2015)" Merger dan Akuisisi dan Dampaknya pada Kinerja Perusahaan: Tampilan Baru "Prosiding DLSU Research Congress, Jilid 3.

[7] Diaw, AD (2014) "The Effect of Merger dan Akuisisi pada Kekayaan Pemegang Saham: Kasus Bank Eropa "Laboratoire d'Économie Dionysienb, Volume 4.

[8] Wibowo, W Amin, A dan Pakereng, Y.M (2001), Pengaruh Pengumuman Merger dan Akuisisi terhadap Return Saham Perusahaan Akuisitor dan Non Akuisitor dalam Sektor Industri Yang Sama di Bursa Efek Jakarta Ekonomi \& Bisnis Indonesia, Vol. 16 No. 4 (Oktober).

[9] Darmawan Syahrial. (2009). Manajemen Keuangan, Mitra Wacana Media.

[10] Hadori Yunus. (2010). Akuntansi Keuangan Lanjutan, BPFE Yogyakarta.

[11] Irham Fahmi. (2014). Manajemen Keuangan Perusahaan, Mitra Wacana Media.

[12] Sutrisno. (2007). Manajemen Keuangan Teori, Konsep dan Aplikasi, Penerbit Ekonomi.

[13] Surat Keputusan Menteri Badan Usaha Milik Negara Nomor: KEP-100/MBU/2002. 